\title{
EFEKTIVITAS KINERJA APARATUR SIPIL NEGARA (ASN) DALAM PELAYANAN PUBLIK DI KANTOR KEMENTERIAN AGAMA KOTA GORONTALO
}

\author{
Agung Nugraha ${ }^{1)}$, Asna Aneta ${ }^{2)}$, Sri Yulianty Mozin ${ }^{3)}$ \\ Universitas Negeri Gorontalo ${ }^{1,2,3)}$ \\ agungnugraha319@gmail.com; Asnaatiek.aneta@ung.ac.id; yulmozin@ung.ac.id
}

\begin{abstract}
ABSTRAK
Penelitian ini bertujuan untuk mengetahui (1) Kinerja ASN dalam pelayanan publik pada Kantor Kementerian Agama Kota Gorontalo, (2) Faktor pendukung dan penghambat untuk mewujudkan efektivitas kinerja ASN dalam pelayanan publik pada Kantor Kementerian Agama Kota Gorontalo. Metode yang digunakan yakni pendekatan kualitatif. Teknik pengumpulan data yang dilakukan dalam penelitian ini yaitu dengan melakukan wawancara pada informan yang terdiri dari Kepala Kantor, Kasubag Kepegawaian dan Kepala Hubungan Masyarakat. Hasil penelitian menunjukkan bahwa Kinerja ASN dalam pelayanan publik pada Kantor Kementerian Agama Kota Gorontalo dilihat dari kualitas kinerja terwujud melalui dimensi tangible (berwujud), reliability (kehandalan), empathy (empati). Namun belum terwujud dalam dimensi responsiviness (respon/ ketanggapan) dan assurance (jaminan). Aspek kuantitas kinerja terwujud melalui penetapan target sesuai kemampuan yang rasional dan mekanisme kerja berdasarkan SOP. Namun belum terwujud dalam penyelesaian pekerjaan sesuai dengan target yang telah ditentukan. Pada aspek ketepatan waktu terwujud melalui ketepatan waktu masuk dan pulang kerja, meninggalkan tempat kerja sesuai izin, dan memaksimalkan waktu kerja di tempat kerja. Namun belum terwujud penyelesaian pekerjaan yang menjadi tugas pokok pada jam kerja. Sedangkan Faktor pendukung untuk mewujudkan efektivitas kinerja ASN dalam pelayanan publik pada Kantor Kementerian Agama Kota Gorontalo yaitu adanya motivasi kerja, pengembangan tingkat pendidikan/ pengalaman kerja sumber daya manusia, serta peralatan dan perlengkapan kerja seperti komputer, printer, gedung dan fasilitas lainnya. Faktor penghambat adalah kurangnya pelatihan pengembangan diri sumber daya manusia dan sarana/ prasarana kerja aplikasi SOP elektronik (e-SOP) yang belum diintegrasikan dalam pelayanan publik pada Kantor Kementerian Agama Kota Gorontalo.
\end{abstract}

Kata kunci: Efektivitas; Kinerja Aparatur Sipil Negara; Pelayanan Publik.

\begin{abstract}
This research aims to find out (1) ASN Performance in public service at the Office of the Ministry of Religious Affairs of Gorontalo City, (2) Supporting factors and inhibition to realize the effectiveness of ASN performance in public service at the Office of the Ministry of Religious Affairs of Gorontalo City. The method used is a qualitative approach. The data collection technique carried out in this study is by conducting interviews on informants consisting of the Head of Office, Staffing Officer and Head of Public Relations. The results showed that asn performance in public service in the Office of the Ministry of Religious Affairs of Gorontalo city is seen from the quality of performance realized through tangible dimensions (tangible), reliability (reliability), empathy (empathy). But it has not materialized in the dimensions of responsiviness and assurance. Aspects of performance quantity are realized through the determination of targets according to rational capabilities and mechanisms of action based on SOP. But it has not yet materialized in the completion of the work in accordance with the target stipulated. In terms of punctuality manifested through punctuality of entry and return to work, leaving the workplace according to permission, and maximizing work time in the workplace. But there has not been a complete work that is the main task in working hours. While supporting factors to realize the effectiveness of ASN performance in public services at the Office of the Ministry of Religious Affairs of Gorontalo city is the development of work motivation, development of education level / work experience of human resources, as well as equipment and work equipment such as computers, printers, buildings and other facilities. The inhibitory factor is the lack of self-development training of human resources and the means / infrastructure of electronic SOP application (e$S O P)$ that has not been integrated in public service at the Office of the Ministry of Religious Affairs of Gorontalo City.
\end{abstract}

Keywords: Effectiveness; Performance of the State Civil Apparatus; Public Service. 


\section{Pendahuluan}

Kinerja ASN yang baik dan optimal adalah sasaran yang ingin dicapai oleh setiap organisasi publik sebagaimana diamanatkan dalam UndangUndang Nomor 5 Tahun 2014 tentang Aparatur Sipil Negara yang menuntut pencapaian kinerja yang tinggi dari ASN.

ASN sebagai penyelenggara pelayanan publik diharapkan dapat memberikan kinerja pelayanan publik yang sebaik-baiknya kepada masyarakat. Pelayanan publik tersebut sebagaimana dalam Pasal 1 Undang-Undang Nomor 25 Tahun 2009 adalah kegiatan atau rangkaian kegiatan dalam rangka pemenuhan kebutuhan pelayanan sesuai dengan peraturan perundang-undangan bagi setiap warga negara dan penduduk atas barang, jasa, dan/ atau pelayanan administratif yang disediakan oleh penyelenggara pelayanan publik.

Kinerja ASN dalam memberikan pelayanan publik di Indonesia secara umum menunjukkan semakin banyak masyarakat yang memberikan respon negatif atau menyatakan rasa tidak puas dengan pelayanan publik. Hal ini berkaitan dengan kinerja ASN dalam organisasi belum efektif. Belum efektifnya kinerja ASN menghambat pencapaian tujuan organisasi publik dalam memberikan pelayanan. Keterlambatan dalam tumbuh kembangnya organisasi publik dan ketidaksuksesan dalam memberikan pelayanan publik ditentukan oleh kinerja ASN yang belum proporsional dan belum maksimal.

Optimalisasi pelaksanaan tugas dan pencapaian kinerja ASN yang efektif telah diupayakan oleh Pemerintah RI dengan menerbitkan Peraturan Pemerintah (PP) Nomor 17 Tahun 2020 tentang Perubahan atas Peraturan Pemerintah Nomor 17 tahun 2017 tentang
Manajemen Pegawai Negeri Sipil. Hal ini dimaksudkan agar ASN dapat melaksanakan pekerjaan yang adaptif dan berintegritas guna meningkatkan kinerja pegawai ASN.

Efektivitas kinerja ASN yang efektif dalam pelayanan publik menjadi perhatian yang sangat penting mengingat tugas pokok pada Kantor Kementerian Agama Kota Gorontalo adalah memberikan pelayanan dibidang urusan keagamaan di Kota Gorontalo. Sebagai organisasi yang melakukan banyak pembinaan, pelayanan dan bimbingan keagamaan di Kota Gorontalo menjadi ujung tombak keberhasilan organisasi dalam perumusan, penetapan dan pelaksanaan kebijakan dibidang keagamaan secara efektif.

Hal ini bisa dilihat dari kinerja ASN berdasarkan penelitian awal pada bulan Desember 2019 sampai Januari 2020. Beberapa masalah yang menyangkut kinerja ASN dalam pelayanan publik yang belum efektif bisa dilihat dari indikator kinerja yaitu kualitas kerja, kuantitas kerja dan ketepatan waktu ASN pada Kantor Kementerian Agama Kota Gorontalo belum maksimal.

Wawancara awal dengan Kasubag Kepegawaian Kantor Kementerian Agama Kota Gorontalo menjelaskan bahwa secara kualitas dan kuantitas, kinerja ASN belum efektif. Dalam hal ini pencapaian hasil kerja ASN dalam menyelesaikan tugas belum tepat sesuai dengan kualitas dan kuantitas kerja atau target yang telah ditentukan. Rata-rata hasil capaian kinerja Kantor Kementerian Agama Kota Gorontalo baik kinerja organisasi dan individu ASN dapat dilihat pada Tabel 1.1. yaitu:
Tabel 1. Perkembangan Kinerja Organisasi Kantor Kementerian Agama Kota Gorontalo 
100

87,23

90,01

89,32

Sumber: Kantor Kementerian Agama Kota Gorontalo Tahun 2020

Capaian kinerja organisasi pada Tabel 1.1. merupakan pencapaian dari indikator-indikator tujuan dan sasaran strategis selama tahun 2017 sampai tahun 2019. Capaian kinerja tersebut adalah presentasi dari akumulasi penilaian terhadap seluruh komponen kinerja organisasi. Walaupun capaian kinerja dalam tiga tahun tersebut berada pada kategori baik yaitu di atas 85 persen, namun belum bisa dikatakan efektif karena belum memenuhi target kinerja yaitu 100 persen.

Kinerja Kantor Kementerian Agama Kota Gorontalo yang belum efektif secara organisasional tentunya tidak lepas dari kinerja individu ASN yang belum efektif. Rekapan hasil penilaian kinerja individu dapat dilihat pada Tabel 1.2. yaitu:

Tabel 2. Perkembangan Rata-rata Kinerja ASN pada Kantor Kementerian Agama Kota Gorontalo

\begin{tabular}{ccc}
\hline Tahun & $\begin{array}{c}\text { Target } \\
\text { Kinerja }(\boldsymbol{\%})\end{array}$ & $\begin{array}{c}\text { Rata-rata Capaian } \\
\text { Kinerja }(\boldsymbol{\%})\end{array}$ \\
\hline 2017 & 100 & 81,20 \\
\hline 2018 & 100 & 82,7 \\
\hline 2019 & 100 & 82,34 \\
\hline
\end{tabular}

Sumber: Kantor Kementerian Agama Kota Gorontalo Tahun 2020

Capaian kinerja rata-rata per individu ASN pada Kantor Kementerian Agama Kota Gorontalo berdasarkan hasil penilaian Satuan Kinerja Pegawai (SKP) menunjukkan penilaian dalam kategori baik, namun belum sesuai target 100 persen. SKP adalah salah satu komponen penting untuk mengukur efektivitas kinerja pegawai pada Kantor Kementerian Agama Kota Gorontalo. Data pada Tabel 1.2 dapat dilihat bahwa kinerja ASN Kantor
Kementerian Agama Kota Gorontalo belum efektif untuk mendukung pelaksanaan tugas dan fungsi Kantor Kementerian Agama Kota Gorontalo.

Kinerja ASN pada Kantor Kementerian Agama Kota Gorontalo yang belum efektif bisa disebabkan oleh beberapa hal. Wawancara awal dengan Kepala Subbagian Tata Usaha Kantor Kementerian Agama Kota Gorontalo menilai bahwa pimpinan masil lemah dalam melakukan pengawasan terhadap proses kerja ASN. Pimpinan belum tegas menindaklanjuti laporan beberapa ASN yang dinilai berkinerja belum sesuai harapan. Selain itu, kinerja ASN belum efektif bisa disebabkan oleh kurangnya motivasi kerja. Beberapa ASN mengeluhkan belum adanya tambahan kesejahteraan melalui insentif yang diharapkan menjadi penyemangat kerja bagi mereka. Beberapa ASN pada Kantor Kementerian Agama Kota Gorontalo belum paham secara detail alur penyelesaian tugas yang menjadi tugas pekerjaannya.

Tujuan penelitian untuk mengetahui (1) kinerja ASN dalam pelayanan publik pada Kantor Kementerian Agama Kota Gorontalo; dan (2) faktor pendukung dan penghambat untuk mewujudkan efektivitas kinerja ASN dalam pelayanan publik pada Kantor Kementerian Agama Kota Gorontalo.

Manfaat penelitian yaitu (1) secara teoritis untuk mengembangkan ilmu pengetahuan berdasarkan beberapa teori administrasi publik; dan (2) secara praktis dapat digunakan oleh manajemen Kantor Kementerian Agama Kota Gorontalo dapat menjadikan rekomendasi penelitian ini sebagai masukan untuk menghasilkan efektivitas kinerja ASN yang baik bagi organisasi. 


\section{Kajian Teori}

\section{Konsep Kinerja}

Rivai (2015) berpendapat "Kinerja adalah hasil atau tingkat keberhasilan pegawai secara keseluruhan selama periode tertentu dalam melaksanakan tugas dibandingkan dengan berbagai kemungkinan, seperti standar hasil kerja, target atau sasaran atau kriteria yang telah ditentukan terlebih dahulu telah disepakati bersama. Jadi dapat dikatakan kinerja pegawai dalam hal ini ASN merupakan totalitas hasil kerja yang berkualitas yang dicapai oleh seorang ASN dalam melaksanakan tugas dan tanggung jawab yang diberikan kepadanya sesuai dengan target yang telah ditentukan.

Silalahi (2019) mengemukakan "Kinerja seseorang pegawai adalah kombinasi dari kemampuan, usaha dan kesempatan yang dapat dinilai dari hasil kerjanya. Pada dasarnya kinerja Aparatur Sipil Negara (ASN) merupakan sesuatu yang bersifat individual, karena setiap Aparatur Sipil Negara (ASN) memiliki tingkat kemampuan yang berbeda dalam mengerjakan tugasnya. Kinerja tergantung pada kombinasi antara kemampuan, usaha, dan kesempatan yang diperoleh". Jadi dapat dikatakan kinerja yang dihasilkan ASN sesuai dengan deskripsi tugas yang dibebankan kepadanya sebagai hasil dari segenap kemampuan dan usaha yang dimilikinya.

\section{Efektivitas Kinerja}

Gibson, dkk (2013) memandang efektivitas dari tiga prepektif, yaitu: 1) Efektivitas individu. Pada prespektif ini menekankan pada pelaksanaan tugas-tugas dan tanggung jawab individu sebagai pekerja dari suatu organisasi. 2). Efektivitas kelompok. Prespektif ini menekankan pada kinerja yang dapat diberikan kelompok pekerja. 3). Efektivitas organisasi. Efektivitas organisasi pada dasarnya merupakan hasil efektivitas individu dan kelompok.

Dalam penelitian ini menyangkut efektvitas kinerja ASN hal ini berarti menekankan pada pelaksanaan tugas-tugas dan tanggung jawab ASN sebagai pelaksana pekerjaan dalam organisasi.

\section{Indikator Efektivitas Kinerja}

Pendapat Saxena (dalam Fauziah, dkk, 2016) terdapat beberapa indikator dalam efektivitas kinerja, yaitu: kualitas, kuantitas, dan ketepatan waktu. Pendapat Wibowo (2017) mengenai ukuran kinerja yang efektif untuk seorang pegawai adalah kuantitas, kualitas, produktivitas, ketepatan waktu, pengawasan biaya. Pendapat Mathis \& Jackson (2015) mengenai kinerja pegawai yang umum untuk kebanyakan pekerjaan meliputi elemen kuantitas dari hasil, kualitas dari hasil, ketepatan waktu dari hasil, kehadiran, dan kemampuan bekerja sama. Jadi dapat dikatakan bahwa efektivitas kinerja dapat dilihat sejauhmana kinerja tersebut efektif yang diindikasikan oleh beberapa indikator. Dalam penelitian ini dikaji efektivitas kinerja dari kualitas, kuantitas, dan ketepatan waktu.

\section{Faktor Pendukung Efektivitas Kinerja}

Penelitian ini akan dilihat faktor-faktor yang mempengaruhi efektivitas kinerja ASN dalam pelayanan publik dari motivasi, sumber daya manusia, dan sarana dan prasarana.

\section{Motivasi}

Pendapat Siagian (2016) "Motivasi adalah daya pendorong yang mengakibatkan seseorang 
anggota organisasi mau dan rela untuk mengarahkan kemampuan dalam bentuk keahlian atau keterampilan, tenaga dan waktu untuk menyelenggarakan berbagai kegiatan yang menjadi tanggung jawabnya, dalam rangka pencapaian tujuan dan berbagai sasaran organisasi yang telah ditentukan sebelumnya".

Nasution (2019) menjelaskan "Motivasi merupakan faktor yang dapat mempengaruhi kinerja. Motivasi merupakan stimulus atau rangsangan yang diberikan kepada seseorang sebagai penyemangat dalam melaksanakan suatu pekerjaan, sehingga dapat lebih bersemangat demi mencapai sasaran dan tujuan yang ingin dicapai hal ini disebabkan karena pekerjaan yang mampu memenuhi unsur kebutuhan seseorang dalam bekerja dapat menjadi motivasi seseorang dalam bekerja". Indikator motivasi dapat diukur dengan unsur kebutuhan seperti penghasilan yang memuaskan, hubungan kerja yang baik, dan mendapatkan penghargaan atau pengakuan dan pengembangan diri atas potensinya yang dapat terpenuhi lewat tugas dan pekerjaannya maka akan mempengaruhi kinerja seseorang sebagai respon atas tugas pekerjaan yang dilakukan.

\section{Sumber daya manusia}

Pendapat Robbins (2015) "Kemampuan pegawai sebagai suatu kapasitas individu untuk mengerjakan berbagai tugas dalam suatu pekerjaan". Kemampuan seseorang individu pada hakekatnya tersusun dari dua perangkat faktor, yaitu kemampuan intelektual dan kemampuan fisik. Kemampuan intelektual adalah kemampuan yang diperlukan untuk menjalankan kegiatan mental. Jadi dapat dikatakan bahwa untuk mewujudkan efektivitas kinerja ASN, maka harus disertai dengan kapasitas individunya untuk mampu menghasilkan kinerja terbaik.

\section{Sarana dan prasarana}

Pendapat Hamzah (2000) menjelaskan bahwa "Sarana dan prasarana kerja yang ada dalam lingkungan organisasi tempat bekerja sebagai faktor pendukung operasional kerja sangatlah diperlukan, hal ini dimaksudkan untuk mempermudah pekerjaan atau gerak aktivitas dalam pengelolaannya, maka diperlukan adanya peralatan yang baik, cukup sesuai kebutuhan, efisien dan efektif serta praktis dalam penggunaannya."

Nasution (2019) menjelaskan sarana kerja ditinjau dari segi kegunaannya terdiri dari 3 (tiga) golongan: a) Peralatan kerja, yaitu semua jenis benda yang berfungsi langsung sebagai alat produksi untuk menghasilkan barang atau berfungsi memproses suatu barang menjadi barang lain yang fungsi dan kegunaannya berbeda; b) Perlengkapan kerja yaitu semua jenis benda yang berfungsi sebagai alat bantu tidak langsung dalam produksi, memepercepat proses, membangkitkan dan menambah kenyamanan dalam pekerjaan; c) Perlengkapan bantu atau fasilitas, yaitu semua jenis benda yang berfungsi membantu melancarkan gerak dalam pekerjaan misalnya alat pendingin ruangan yang tidak kalah pentingnya adalah keberadaan ruang fasilitas pendukung pelayanan, antara lain adalah fasilitas, ruangan yang memadai seperti ruangan pelayanan yang cukup luas untuk memproses berkas-berkas, bagian informasi yang lengkap. 
Pelayanan publik dalam Keputusan Menteri Pendayagunaan Aparatur Negara Nomor 25 tentang Pelayanan Publik Tahun 2004 berarti segala kegiatan pelayanan yang dilaksanakan oleh penyelenggaraan pelayanan publik sebagai upaya pemenuhan kebutuhan penerima pelayanan maupun dalam rangka pelaksanaan ketentuan peraturan undang-undangan.

Pendapat Aneta dan Tohopi (2017) "Pelayanan publik adalah adalah istilah untuk layanan yang disediakan oleh pemerintah kepada warga negaranya, baik secara langsung (melalui sektor publik) atau dengan membiayai pemberian layanan swasta. Layanan ini disediakan untuk masyarakat, baik secara umum atau secara khusus dan merupakan kepercayaan publik.

Pendapat Cahyadi (2016) bahwa pelayanan publik dapat diartikan sebagai pemberian layanan (melayani) keperluan orang atau masyarakat yang mempunyai kepentingan pada organisasi itu sesuai dengan aturan pokok dan tata cara yang telah ditetapkan.

\section{Aparatur Sipil Negara}

Pegawai adalah orang orang yang melakukan pekerjaan dengan mendapat imbalan jasa berupa gaji dan tunjangan dari pemerintah atau badan swasta. Pegawai sebagai pekerja atau worker adalah mereka yang langsung digerakkan oleh seorang manager untuk bertindak sebagai pelaksana yang akan menyelenggarakan pekerjaan, sehingga menghasilkan karya-karya yang diharapkan dalam usaha pencapaian tujuan organisasi yang telah ditetapkan (Musanef, 2011).

Sunda, dkk (2017) menjelaskan jenis-jenis aparatur adalah:
1. Aparatur Negara Aparatur negara adalah keseluruhan pejabat dan lembaga negara serta pemerintahan negara yang meliputi aparatur kenegaraan dan pemerintahan, sebagai abdi negara dan abdi masyarakat bertugas dan bertanggung jawab atas penyelenggaraan negaraan pembangunan serta senantiasa mengabdi dan setia kepada kepentingan, nilainilai dan cita-cita perjuangan bangsa dan negara berdasarkan Pancasila dan UUD 1945.

2. Aparatur Pemerintah Aparatur pemerintah adalah keseluruhan lembaga atau badan yang berada dibawah Presiden seperti departemen, lembaga pemerintahan dan departemen serta sekretariat departemen dan lembaga-lembaga tinggi negara.

3. Aparatur Perekonomian Negara Aparatur perekonomian negara adalah keselurhan bank pemerintah, lembaga perkreditan, lembaga keuangan. Pasar uang dan modal serta perusahaan milik negara dan perusahaan milik daerah.

\section{Efektivitas Kinerja ASN dalam Pelayanan} Publik

Dewasa ini perubahan demi perubahan dalam meningkatkan efektivitas kinerja ASN selalu menjadi fokus utama dalam meningkatkan pelayanan publik bagi masyarakat, hal ini dipandang penting guna meningkatkan kinerja ASN.

Pendapat Kadarisman (2019) mengatakan bahwa efektifitas kinerja ASN menentukan keberhasilan organisasi, tujuan akhirnya berupa kepuasan publik atas pelayanan yang didapatkan. Adanya kerjasama yang baik dalam menyelesaikan 
beban tugas, dan pemanfaatan waktu secara optimal, sehingga dapat mencapai sasaran kerja individu dan tim sesuai perencanaan.

Ketidakefektifan dalam bekerja akan menghambat dalam pelaksanaan pencapaian tujuan dalam pelayanan publik. Efektivitas kinerja ASN dalam organisasi merupakan usaha untuk mencapai prestasi yang maksimal dengan menggunakan sumber daya yang tersedia dalam waktu yang relatif singkat tanpa menunggu keseimbangan tujuan alat dan tenaga serta waktu.

\section{Metode}

Jenis penelitian ini adalah penelitian deskriptif kualitatif. Waktu penelitian selama 6 (enam) bulan sejak bulan Februari sampai Juli 2020. Target/Subjek Penelitian memiliki keterkaitan dengan permasalahan efektivitas kinerja ASN pada Kantor Kementerian Agama Kota Gorontalo, dengan informan Kepala Kantor Kementerian Agama Kota Gorontalo, Kasubag Kepegawaian dan Kepala Hubungan Masyarakat. Teknik Pengumpulan Data (1) teknik wawancara dengan informan dilakukan secara terarah, bebas dan mendalam (in-depth), (2) teknik observasi tidak berstruktur dilakukan dengan bantuan pedoman atau panduan observasi, dan (3) teknik dokumenter untuk menelusuri dokumen resmi yang berkaitan dengan fokus penelitian. Teknik analisis data dalam penelitian ini dilakukan dengan reduksi data, penyajian data dan penarikan kesimpulan/verifikasi.

\section{Hasil Dan Pembahasan}

\section{Kinerja ASN dalam pelayanan publik}

Kualitas kinerja merupakan sikap yang ditujukkan oleh ASN pada Kantor Kementerian Agama Kota Gorontalo berupa hasil kerja dalam pelayanan publik dilihat dari: tangible (berwujud), reliability (kehandalan), responsiviness, assurance (jaminan), dan empathy (empati).

Hasil penelitian menunjukkan bahwa para ASN di kantor Kementerian Agama Kota Gorontalo terutama yang bertugas dalam bidang pelayanan administrasi kepegawaian yang berhubungan langsung dengan penerima layanan yaitu guru di madrasah, guru bimas, dan guru pendidikan agama, tenaga administrasi umum, penyuluh agama, dan lainnya, para ASN ini sudah memiliki penampilan yang baik dalam arti dari segi berpakaian sudah baik. Kami juga telah mengupayakan tempat pelayanan yang nyaman bagi penerima layanan. Mereka dapat memperoleh kemudahan dalam proses pelayanan yang diterima. Urut-urutan langkah dalam pelayanan di kantor ini jelas, berdasarkan prosedur di masing-masing unit yang ada aturan dan SOP. Rata-rata ASN di kantor ini mampu menggunakan sarana kerja dan fasilitas yang ada. Sebagai wujud dari profesionalitas, maka setiap ASN melayani dengan sikap ramah dan sopan santun. SOP itu hanya mengatur prosedur dan alur pelayanan, belum mengatur waktu yang dibutuhkan untuk penyelesaian setiap item pekerjaan.

Hasil penelitian menunjukkan kualitas kinerja ASN dalam memberikan pelayanan publik pada Kantor Kementerian Agama Kota Gorontalo terwujud melalui dimensi tangible (berwujud), reliability (kehandalan) dan empathy (empati). Sedangkan dimensi responsiviness (respon/ ketanggapan) dan assurance (jaminan) belum dapat mewujudkan kualitas kinerja ASN dalam memberikan pelayanan publik pada Kantor Kementerian Agama Kota Gorontalo. 
Hasil penelitian ini sesuai dengan penelitian Rukayat (2018) dapat dijelaskan bahwa terwujudnya tangible (berwujud) pada Kantor Kementerian Agama Kota Gorontalo sangat penting dan salah satu yang sangat berpengaruh terhadap peningkatan kualitas dalam pelayanan publik karena dengan adanya sarana pelayanan yang memadai dapat membuat pelayanan pada masyarakat dapat lebih memberikan kenyamanan dan kepuasan selama berada di ruangan pelayanan. Sementara itu, terwujudnya dimensi reliability (kehandalan) ASN pada Kantor Kementerian Agama Kota Gorontalo dalam memberikan suatu jasa dengan segera, akurat dan memuaskan sangat diperlukan agar terciptanya kepuasan dalam diri pelanggan. Sedangkan terwujudnya empathy (empati) menunjukkan Kantor Kementerian Agama Kota Gorontalo selalu siap dalam membantu masyarakat yang membutuhkan pelayanan. Kepedulian ASN pada Kantor Kementerian Agama Kota Gorontalo untuk selalu mengutamakan kebutuhan masyarakat akan mendukung terciptanya kualitas kinerja ASN dalam pelayan publik.

Kuantitas kinerja merupakan volume kerja yang dihasilkan ASN dalam pelayanan publik pada Kantor Kementerian Agama Kota Gorontalo dilihat dari banyaknya beban kerja dan keadaan yang didapat atau dialami ASN selama bekerja yaitu penetapan target sesuai kemampuan yang rasional, penyelesaian pekerjaan sesuai dengan target yang telah ditentukan, dan mekanisme kerja berdasarkan Standard Operating Procedure (SOP).

Hasil penelitian menunjukkan kuantitas kinerja ASN dalam memberikan pelayanan publik pada Kantor Kementerian Agama Kota Gorontalo terwujud melalui penetapan target sesuai kemampuan yang rasional dan mekanisme kerja berdasarkan SOP. Sedangkan penyelesaian pekerjaan sesuai dengan target yang telah ditentukan belum dapat mewujudkan kuantitas kinerja ASN dalam memberikan pelayanan publik pada Kantor Kementerian Agama Kota Gorontalo.Sesuai dengan penelitian Widiaswari (2016), hasil penelitian ini menunjukkan terwujud melalui penetapan target sesuai kemampuan yang rasional dan mekanisme kerja berdasarkan SOP. Dengan mempertimbangkan kemampuan rasional dari ASN maupun sumber daya anggaran dan sumber daya peralatan pada organisasi Kantor Kementerian Agama Kota Gorontalo, maka diharapkan secara kuantitas hasil pekerjaan pelayanan publik pada Kantor Kementerian Agama Kota Gorontalo dapat memenuhi indikator volume jumlah pekerjaan yang dihasilkan sesuai dengan ketentuan-ketentuan yang berlaku pada Kantor Kementerian Agama Kota Gorontalo tersebut, agar tidak terjadi kekeliruan atau penyimpangan dari standar yang ditentukan.

Ketepatan waktu adalah penggunaan jam kerja oleh ASN dalam pelayanan publik yang disesuaikan dengan kebijakan Kantor Kementerian Agama Kota Gorontalo agar pekerjaan selesai tepat waktu yang ditentukan dilihat dari ketepatan waktu masuk dan pulang kerja, meninggalkan tempat kerja sesuai izin, memaksimalkan waktu kerja di tempat kerja dan menyelesaikan pekerjaan yang menjadi tugas pokok pada jam kerja.

Hasil penelitian menunjukkan ketepatan waktu ASN dalam memberikan pelayanan publik pada Kantor Kementerian Agama Kota Gorontalo terwujud melalui ketepatan waktu masuk dan pulang kerja, meninggalkan tempat kerja sesuai 
izin, dan memaksimalkan waktu kerja di tempat kerja. Sedangkan penyelesaian pekerjaan yang menjadi tugas pokok pada jam kerja belum dapat mewujudkan ketepatan waktu ASN dalam memberikan pelayanan publik pada Kantor Kementerian Agama Kota Gorontalo.

\section{Faktor pendukung dan penghambat untuk mewujudkan efektivitas kinerja ASN dalam pelayanan publik}

Motivasi ASN dalam menghasilkan kinerja yang efektif merupakan kebutuhan atau dorongan dalam diri ASN tersebut untuk melakukan sesuatu yang akan memuaskan dirinya. Seseorang ASN bertindak karena adanya sejumlah kekuatan yang mendorong dirinya untuk menghasilkan kinerja yang lebih baik dapat dilihat dari penghasilan yang memuaskan, hubungan kerja yang baik, penghargaan atau pengakuan.

Hasil penelitian menunjukkan motivasi kerja dalam bentuk penghasilan yang memuaskan, hubungan kerja yang baik, dan penghargaan atau pengakuan menjadi faktor pendukung untuk mewujudkan efektivitas kinerja ASN dalam pelayanan publik pada Kantor Kementerian Agama Kota Gorontalo. Sesuai teori Nasution (2019), hasil penelitian ini menunjukkan motivasi merupakan faktor yang dapat mempengaruhi efektivitas kinerja ASN dalam pelayanan publik pada Kantor Kementerian Agama Kota Gorontalo.

Sumber daya manusia adalah kemampuan ASN dalam pelayanan publik pada Kantor Kementerian Agama Kota Gorontalo sebagai suatu kapasitas individu untuk mengerjakan berbagai tugas dalam suatu pekerjaan dapat dilihat dari tingkat pendidikan, pengalaman dan pelatihan.
Setiap ASN Kemenag Kota Gorontalo memiliki peluang dan kesempatan untuk melakukan studi lanjut dan pelatihan teknis. Berbagai program pengembangan SDM yang disediakan oleh kantor telah membawa perubahan bagi kinerja professional. Namun pelatihan yang diikuti oleh ASN lebih banyak ke arah pelatihan teknis yang lebih berfokus pada pengetahuan dan kemampuan untuk melaksanakan tugas tertentu, baik secara fisik maupun mental. Seharusnya porsi yang banyak juga difokuskan pada pelatihan kepribadian yang dapat membentuk watak ASN yang bisa menyesuaikan diri dengan segala sesuatu".

Hasil penelitian menunjukkan sumber daya manusia dari pengembangan tingkat pendidikan dan pengalaman kerja menjadi faktor pendukung untuk mewujudkan efektivitas kinerja ASN dalam pelayanan publik pada Kantor Kementerian Agama Kota Gorontalo. Sedangkan dari aspek kurangnya pelatihan pengembangan diri menjadi faktor penghambat untuk mewujudkan efektivitas kinerja ASN dalam pelayanan publik pada Kantor Kementerian Agama Kota Gorontalo. Jadi dapat dikatakan bahwa untuk mewujudkan efektivitas kinerja ASN ASN pada Kantor Kementerian Agama Kota Gorontalo dalam pelayanan publik, maka harus disertai dengan kapasitas individunya untuk mampu menghasilkan kinerja terbaik. Oleh karena itu, ASN pada Kantor Kementerian Agama Kota Gorontalo harus tetap mengembangkan kemampuan dirinya baik melalui studi lanjut dan pelatihan teknis lainnya.

Sarana dan prasarana kerja adalah peralatan dan perlengkapan kerja serta alat bantu untuk melakukan pelayanan publik yang ada dalam lingkungan Kantor Kementerian Agama Kota 
Gorontalo dapat dilihat dari ketersediaan dan penggunaan sarana dan prasarana kerja.

Sarana dan prasarana kantor sudah memadai untuk menunjang pelayanan. Namun ada satu kendala yang kami hadapi terkait pengarsipa SOP. Seharusnya kami sudah menggunakan e-SOP. Sistem ini belum diterapkan di kantor Kemenag Kota Gorontalo, sehingga SOP tidak terarsip dengan baik, seringkali ketika SOP itu dicari, sulit untuk menemukan. Ini akan menjadi prioritas kami kedepan untuk tersedianya dan dapat digunakannua $e-S O P$.

Hasil penelitian menunjukkan peralatan dan perlengkapan kerja seperti komputer, printer, gedung dan fasilitas lainnya menjadi faktor pendukung untuk mewujudkan efektivitas kinerja ASN pada Kantor Kementerian Agama Kota Gorontalo dalam pelayanan publik. Sedangkan alat bantu dalam bentuk aplikasi SOP elektronik ( $e$ SOP) yang belum diintegrasikan pada Kantor Kementerian Agama Kota Gorontalo dalam pelayanan publik menjadi faktor penghambat untuk mewujudkan efektivitas kinerja ASN pada Kantor Kementerian Agama Kota Gorontalo dalam pelayanan publik.

\section{Penutup}

\section{Kesimpulan}

1. Kinerja ASN dalam pelayanan publik pada Kantor Kementerian Agama Kota Gorontalo dilihat dari kualitas kinerja terwujud melalui dimensi tangible (berwujud), reliability (kehandalan), empathy (empati). Namun belum terwujud dalam dimensi responsiviness (respon/ ketanggapan) dan assurance (jaminan). Dilihat dari kuantitas kinerja terwujud melalui penetapan target sesuai kemampuan yang rasional dan mekanisme kerja berdasarkan SOP. Namun belum terwujud dalam penyelesaian pekerjaan sesuai dengan target yang telah ditentukan. Dilihat dari ketepatan waktu terwujud melalui ketepatan waktu masuk dan pulang kerja, meninggalkan tempat kerja sesuai izin, dan memaksimalkan waktu kerja di tempat kerja. Namun belum terwujud penyelesaian pekerjaan yang menjadi tugas pokok pada jam kerja.

2. Faktor pendukung untuk mewujudkan efektivitas kinerja ASN dalam pelayanan publik pada Kantor Kementerian Agama Kota Gorontalo yaitu adanya motivasi kerja, pengembangan tingkat pendidikan/ pengalaman kerja sumber daya manusia, serta peralatan dan perlengkapan kerja seperti komputer, printer, gedung dan fasilitas lainnya. Sedangkan faktor penghambat adalah kurangnya pelatihan pengembangan diri sumber daya manusia dan sarana/ prasarana kerja aplikasi SOP elektronik (e-SOP) yang belum diintegrasikan dalam pelayanan publik pada Kantor Kementerian Agama Kota Gorontalo.

\section{Saran}

1. Kinerja ASN dalam pelayanan publik pada Kantor Kementerian Agama Kota Gorontalo perlu ditingkatkan dari segi respon ketanggapan dalam memberikan pelayanan publik. Demikian juga untuk memberikan jaminan bagi yang dilayani, maka perlu adanya kepastian waktu dan biaya pelayanan yang diinformasikan kepada penerima pelayanan baik melalui pengumuman, website Kantor Kementerian Agama Kota Gorontalo dan media lainnya. 
2. Kantor Kementerian Agama Kota Gorontalo perlu mencantumkan penyelesaian pekerjaan yang menjadi tugas pokok pada jam kerja dalam SOP kantor.

3. Kantor Kementerian Agama Kota Gorontalo perlu mengembangkan berbagai program motivasi kerja, seperti reward naik haji dan umroh bagi pegawai berprestasi.

4. Kantor Kementerian Agama Kota Gorontalo perlu menyelenggarakan pelatihan pengembangan diri bagi ASN, dan ASN perlu melibatkan dirinya dalam pelatihan ini.

5. Kantor Kementerian Agama Kota Gorontalo perlu mencantumkan standar pelayanan minimum baik seluruh pekerjaan pada Kantor Kementerian Agama Kota Gorontalo berdasarkan SPM (Standar Pelayanan Minimum) dalam hal ini waktu penyelesaian dokumen tertera jumlah waktu terselesaikan, jumlah biaya yang harus dikeluarkan oleh masyarakat/ pengguna jasa. Sehingga tidak ragu-ragu membayar hasil produk karena semua sudah diatur oleh peraturan.

\section{Referensi}

Aneta, A., \& Tohopi, R. (2017). Mewujudkan Good Governance Melalui Standar Pelayanan Minimal (SPM) Dinas Kesehatan Kota Gorontalo.diseminarkan pada IAPA National Conference yang dilaksanakan pada tanggal 19 Oktober di Universitas Indonesia. repository.ung.ac.id.

Cahyadi, R. (2016). Inovasi kualitas pelayanan publik pemerintah daerah. Fiat Justicia Jurnal Ilmu Hukum Fakultas Hukum Universitas Lampung, 10(3), 569-586.

Hamzah. (2000). Analisis Kinerja Aparatur Badan Perencanaan Pembangunan Daerah
Kabupaten Kutai. Tesis Yang Tidak Dipublikasikan.

Kadarisman, M. (2019). Efektivitas Kinerja Aparatur Sipil Negara Dalam Pelayanan Administrasi di Kota Depok. Jurnal Ilmu Administrasi: Media Pengembangan Ilmu dan Praktek Administrasi, 16(1), 17-32.

Mathis, R.L., dan Jackson, J.H. (2015). Human Resource Management, terjemahan. Jakarta: Salemba Empat.

Musanef. (2011). Manajemen Kepegawaian Indonesia. Jakarta: Gunung Agung.

Nasution, D. A. D. (2019). Faktor-Faktor Yang Mempengaruhi Kinerja Pengguna Sistem Informasi Manajemen Daerah-Keuangan Pemerintah Provinsi Sumatera Utara. Jurnal Akuntansi Bisnis dan Publik, 10(1), 101114.

Rivai, V. (2015). Manajemen Sumber Daya Manusia Untuk Perusahaan Dari Teori ke Praktek. Bogor: Ghalia Industri.

Robbins, S.D. (2015). Perilaku Organisasi. Jakarta: Salemba Empat.

Rukayat, Y. (2018). Kualitas Pelayanan Publik Bidang Administrasi Kependudukan Di Kecamatan Pasirjambu. Jurnal Ilmiah Magister Administrasi, 11(2)

Rukayat, Y. (2018). Kualitas Pelayanan Publik Bidang Administrasi Kependudukan Di Kecamatan Pasirjambu. Jurnal Ilmiah Magister Administrasi, 11(2).

Siagian, S.P. (2016).Manajemen Sumber Daya Manusia. Jakarta: Bumi Aksara.

Silalahi, S. M. (2019). Pengaruh Budaya Organisasi dan Semangat Kerja Terhadap Kinerja ASN (Aparatur Sipil Negara) pada Dinas Tenaga Kerja Provinsi Sumatera Utara. http://repository.uhn.ac.id/handle/12345678 $\underline{9 / 2265}$

Sunda, C. M., Lumolos, J., \& Sambiran, S. (2017). Kinerja Aparatur Sipil Negara dalam Pelayanan Publik Di Kelurahan Talikuran 
Kecamatan Kawangkoan Utara. Jurnal Eksekutif, 1(1), 1-12.

Wibowo. (2017). Manajemen Kinerja. Depok: PT.

Raja Grafindo.

\section{Dokumen}

Undang Undang Nomor 5 Tahun 2014 tentang Aparatur Sipil Negara.

Undang-Undang Nomor 25 Tahun 2009 tentang Pelayanan Publik. 